\title{
A Systematic Review on Estimation of Reference Evapotranspiration under Prisma Guidelines
}

\author{
Ali Raza ${ }^{1}$, Yongguang $\mathrm{Hu}^{1 *}$, Muhammad Shoaib ${ }^{2}$, Manar K. Abd Elnabi ${ }^{3}$, \\ Muhammad Zubair ${ }^{4}$, Muhammad Nauman ${ }^{5}$, Neyha Rubab Syed ${ }^{6}$ \\ ${ }^{1}$ School of Agricultural Equipment Engineering, Jiangsu University, Zhenjiang 212013, P.R. China \\ ${ }^{2}$ Department of Agricultural Engineering, Bahauddin Zakariya University, Multan-Pakistan \\ ${ }^{3}$ Botany Department, Faculty of Science, Tanta University, Tanta, 31527, Egypt \\ ${ }^{4}$ School of Transportation, Southeast University, Nanjing 21009, China \\ ${ }^{5}$ School of Energy and Power Engineering, Jiangsu University, Zhenjiang 212013, P.R. China \\ ${ }^{6}$ Department of Environmental Sciences International Islamic University Islamabad-Pakistan
}

Received: 8 December 2020

Accepted: 8 April 2021

\begin{abstract}
Reference evapotranspiration (ET) is considered an essential factor in determining the meticulous estimation of crop water requirement and effective irrigation scheduling. The accurate estimation of crop water requirement is of critical importance to minimize over and under irrigation problems. Several empirical/semi empirical equations have been developed in the past to quantify $\mathrm{ET}_{\mathrm{o}}$. The Penmen-Montieth equation (FAO-PM56) has been globally accepted for estimation of $\mathrm{ET}_{\mathrm{o}}$ but certain limitations were found to its implementation. The use of soft computing models in estimation of $\mathrm{ET}_{\mathrm{o}}$ has received enormous interest in recent decade. Many studies have been reported in the literature to apply soft computing models on the improvement of $\mathrm{ET}_{\mathrm{o}}$ estimation. This study intended to review these studies on basis of accuracy, structure and its flexibility/usefulness, and also made some possible suggestions for future research in this domain.
\end{abstract}

Keywords: reference evapotranspiration, empirical/semi-empirical equation, soft computing models, challenges and issues, diverse climatic stations

\section{Introduction}

Mitigation of water shortage has become a critical issue of the $21^{\text {st }}$ century and labeled as blue gold. The agriculture sector is ranked as the highest consumptive user of water in most of the countries. The water withdrawal from the total amount of water in developing

*e-mail: deerhu@ujs.edu.cn counties is estimated nearly $81 \%$ while it is accounted for $71 \%$ globally. In addition, more than $55 \%$ of all the world's fresh water withdrawals are allocated towards irrigation use [1]. Reference evapotranspiration (ET) is the principal component of the global hydrological cycle which affects irrigation, water requirement and crops yield. It consists of evaporation and transpiration processes. The phenomenon in which water moves from the land surface to the atmosphere is called evaporation while transpiration is the process in which plant roots 
extract water from the root zone and transport it to the leaves where it is lost through stomata [2]. For the purpose of the reference surface, a substantially uniform field of alfalfa (or grass) is considered worldwide. The characteristic of a reference surface crop includes the soil's properties, uniform height and total amount of water use under standard meteorological and agronomical conditions [3].

Estimation of ET is considered an essential element in the regional and global scale, preparation of water budget, crop irrigation requirements and influence of climate variation [4]. According to Lu et al. [5] and Zhao et al. [6], quantification of $\mathrm{ET}_{\mathrm{o}}$ has always been difficult due to an imperceptible process exclusively in an ecosystem or a watershed spatial scale with the desired level of accuracy. Determining the soil water balance (especially $\mathrm{ET}_{\mathrm{o}}$ component) is of great importance for good irrigation planning and management. As the soil has limited capacity to contain water, knowing the soil water balance overcomes the risk to apply excessive amounts of water which results in high percolation or overflow [6].

The estimation of $\mathrm{ET}_{\mathrm{o}}$ through lysimeter is considered the best choice for direct measurement but a hard chore because it is time consuming and also requires potential financial aid. This method is not viable due to tedious and imprecise planning. Consequently, the indirect and soft computing models have gained much importance for estimating $\mathrm{ET}_{\mathrm{o}}$ from climatic data [7]. McMahon et al. [8] have categorized indirect methods into following types: (1) empirical and semi empirical equations (2) Pan-evaporation method (3) energy budget method (4) mass transfer equations (5) combination equations (6) radiation base methods. In addition, empirical/semi-empirical equation based priestly-Taylor and penmen montieth methods have been widely used for estimation of ET [9]. Numerous methods/approaches have been developed for the estimation of $\mathrm{ET}_{\mathrm{o}}$. These methods/approaches were used in different regions of the world and it worked efficiently where they were developed. When such approaches/ methods were applied in other climatic regions, the results were quite inefficient and not satisfying in comparison to conventional adopted methods [10].

One of the well-known indirect methods has been introduced by Food and Agriculture Organization (FAO) of United Nations which is accepted worldwide for $\mathrm{ET}_{\mathrm{o}}$ estimation. This method includes incorporation of Penman-Monteith equation which was altered and reformed by Allen et al. [11] as symbolized as FAOPM56. This method must be affected and controlled by several aerodynamic, surface resistance and climatic parameters. These consist of maximum and minimum air temperature, wind speed and solar radiation, deficit of saturation vapor pressure, slope vapor pressure curve, maximum and minimum relative air humidity and psychrometric constant. There is an anomaly to air temperature available at several weather stations. The remaining variables are usually incomplete and not always found reliable for several locations [12]. In the developed countries this may be not valid but in cases of developing countries, it considers a big challenge, where quantity and quality of data, always remain questionable. The reliable weather data sets of radiation, wind speed and relative humidity are often limited in developing countries as reported by Trajkovic and Kolakovic [13]. In addition, the geographic data (latitude, longitude, altitude) is also necessary in FAO-PM56 for the local adjustment of the various weather parameters, e.g. extraterrestrial radiations, atmospheric pressure, and daylight hours [14].

Thus, alternative computer based soft computing models have been developed and reported in the literature over a last decade to omit limitations of FAOPM56 method and try to estimate ET by using limited climatic parameters. The formulation of $\mathrm{ET}_{\mathrm{o}}$ model with use of novel learning algorithms, input/output dataset and activation functions in soft computing models attained much attention in achieving high performance. In this study, ET estimation by applying various soft computing models in comparison to FAO-PM56 and empirical/semi-empirical equations existed in literature have been reviewed on the basis of accuracy, structure and flexibility/usefulness.

\section{Development of Soft Computing Models}

Kumar et al. [15] have categorized ET estimation into energy based, temperature based, mass transfer and composite based methods. These methods are based on various empirical and semi-empirical equations which can be observed in Table 1. It can be perceived that selection of particular method depends upon weather type and nature of surface area. The weather divided into saturated, semi saturated, semi dry and dry conditions while surface area into valley, grassy land, vegetative surface, lake surface, water free surface and grass type. Beside each method, only composite method based on FAO-PM56 equations acknowledged as standard and considered viable for each type of weather and surface area. The applicability of FAO-PM56 equation become limited due to large amount of climatic and aerodynamic parameters requirement. Therefore, various researches conducted on $\mathrm{ET}_{\mathrm{o}}$ estimation in different part of world and reported in recent decade.

The application of soft computing models have been widely used for non-linear phenomena in hydrological studies [16]. As the process of $\mathrm{ET}_{\mathrm{o}}$ considered nonlinear dynamic and complex in nature, soft computing models can be contemplated as alternative tool. These models are based on computational intelligent system to overcome imprecision and vulnerability in producing results. The topology in development of soft computing model for $\mathrm{ET}_{\mathrm{o}}$ estimation is presented in Fig. 1. The selection of best suitable soft computing model depends upon model's structure, accuracy and usefulness. 
Table 1. Types of ET estimation method based on empirical/semi-empirical equations.

\begin{tabular}{|c|c|c|c|}
\hline Type & Equation & Weather condition & surface area \\
\hline \multirow{7}{*}{$\begin{array}{c}\text { Energy } \\
\text { based method }\end{array}$} & $\mathrm{ET}=\mathrm{ET} \frac{\mathrm{dN}}{360}, \mathrm{ET}^{\prime}=\mathrm{C}\left(\frac{10 \mathrm{Ta}}{\mathrm{I}}\right)^{\mathrm{a}} \mathrm{i}=\left(\frac{\mathrm{Ta}}{5}\right)^{1.51}=\sum_{\mathrm{j}=1}^{12} \mathrm{j}$ & Saturated & Valley \\
\hline & $\mathrm{ET}=\mathrm{a} \frac{\Delta}{\Delta+\gamma} \frac{\mathrm{R}_{\mathrm{s}}}{\lambda}-\beta_{, \alpha=0.61, \beta=0.12}$ & Saturated & Grassy land \\
\hline & $\begin{array}{l}\mathrm{ET}=0.013 \frac{\mathrm{T}}{\mathrm{T}+15}\left(\mathrm{R}_{\mathrm{s}}+50\right) \mathrm{RH}>50 \\
\mathrm{ET}=0.013 \frac{\mathrm{T}}{\mathrm{T}+15}\left(\mathrm{R}_{\mathrm{s}}+50\right)\left(1+\frac{50-\mathrm{RH}}{70}\right)\end{array}$ & Saturated & Grassy land \\
\hline & $\begin{array}{l}\mathrm{ET}=\mathrm{C}_{\mathrm{t}}\left(\mathrm{T}-\mathrm{T}_{\mathrm{x}}\right) \frac{\mathrm{R}_{\mathrm{s}}}{\lambda} \\
\mathrm{Ct}=0.025 ; \mathrm{T}_{\mathrm{x}}=-3\end{array}$ & Saturated and semi-saturated & Grassy land \\
\hline & $\begin{array}{l}\mathrm{ET}=\mathrm{a} \frac{\Delta}{\Delta+\gamma} \frac{\mathrm{R}_{\mathrm{n}}}{\lambda} \\
\alpha=1.26\end{array}$ & Saturated Humid; wet surface & Hydrated surface \\
\hline & $\mathrm{ET}=0.0135(\mathrm{~T}+17.8) \frac{\mathrm{R}_{\mathrm{s}}}{\lambda}$ & Dry and semi-dry & Grassy land \\
\hline & $\begin{array}{l}\mathrm{ET}=\mathrm{a}\left(\frac{\Delta}{\Delta+\gamma} \frac{\mathrm{R}_{\mathrm{s}}}{\lambda}\right)+\mathrm{b} \\
\mathrm{b}=0.03\end{array}$ & Saturated & Grassy land \\
\hline \multirow{4}{*}{$\begin{array}{l}\text { Temperature based } \\
\text { method }\end{array}$} & $\mathrm{ET}=0.55 \mathrm{D}^{2} \mathrm{Pt} \quad \mathrm{ET}=\mathrm{Kp}(0.46 \mathrm{~T}+8.13)$ & Dry and semi-dry & Vegetative surface \\
\hline & $\mathrm{Pt}=\frac{4.95 \mathrm{e}^{\left(0.062 \mathrm{~T}_{\mathrm{a}}\right)}}{100}$ & All type & Vegetative surface \\
\hline & $\mathrm{ET}=\frac{\frac{500 \mathrm{~T}_{\mathrm{m}}}{100-\mathrm{A}}+15\left(\mathrm{~T}_{\mathrm{a}}-\mathrm{T}_{\mathrm{d}}\right)}{\left(80-\mathrm{T}_{\mathrm{a}}\right)}$ & All type & Lake surface \\
\hline & $\mathrm{ET}=0.34 \rho \mathrm{T}_{\mathrm{a}}^{1.3}$ & Dry & Vegetative surface \\
\hline \multirow{2}{*}{$\begin{array}{l}\text { Mass transfer } \\
\text { method }\end{array}$} & $\mathrm{ET}=0.35\left(1+\frac{0.98}{100 \mathrm{U}_{2}}\right)\left(\mathrm{e}_{\mathrm{s}}-\mathrm{e}_{\mathrm{a}}\right)$ & Saturated & Water free surface \\
\hline & $\mathrm{ET}=0.44\left(1+0.27 \mathrm{U}_{2}\right)\left(\mathrm{e}_{\mathrm{s}}-\mathrm{e}_{\mathrm{a}}\right)$ & Dry and semi-dry & Water free surface \\
\hline Composite method & $\mathrm{ET}=\frac{0.48 \Delta\left(\mathrm{R}_{\mathrm{N}}\right)+\gamma \frac{900}{\left(\mathrm{~T}_{\mathrm{a}}+273\right)} \mathrm{U}_{2}\left(\mathrm{e}_{\mathrm{s}}-\mathrm{e}_{\mathrm{a}}\right)}{\Delta+\gamma\left(1+0.34 \mathrm{U}_{2}\right)}$ & All type & Grass \\
\hline
\end{tabular}

Several factors including hidden/output layer, weights and neurons, activation functions, network and other tuning parameters helped in determining suitable model. These factors are explicitly explained in Raza et al. [17-18]. It was noted that these models produced good results using fewer inputs which resembled with field calculations. The development of these models using limited dataset without involving physical process information made them superior over conventionally adopted empirical/semi-empirical equations and urge to use [19].

\section{Review Methodology: PRISMA Guidelines}

The guidelines of preferred reporting items for systematic review and meta-analysis (PRISMA) were followed for conducting systematic review in this study.

\section{Data Source}

The searching of research articles was performed in google scholar database only. The following keywords were used individually and along with combinations for seeking relevant results: reference evapotranspiration, soft computing, machine learning, artificial neural network, climatic variables, climatic stations, Penmen Montieth equation, ET.

\section{Screening of Articles and Data Collection}

The following inclusion criteria for the selected research articles was carried out: only English language based scientific articles, published articles available in full text and indexed in scientific journals. However, the studies belong to incompatible results, dissertations, books and unpublished work were excluded in this study. A total of 143,000 research articles were significantly identified. Based on inclusion and exclusion criteria, 


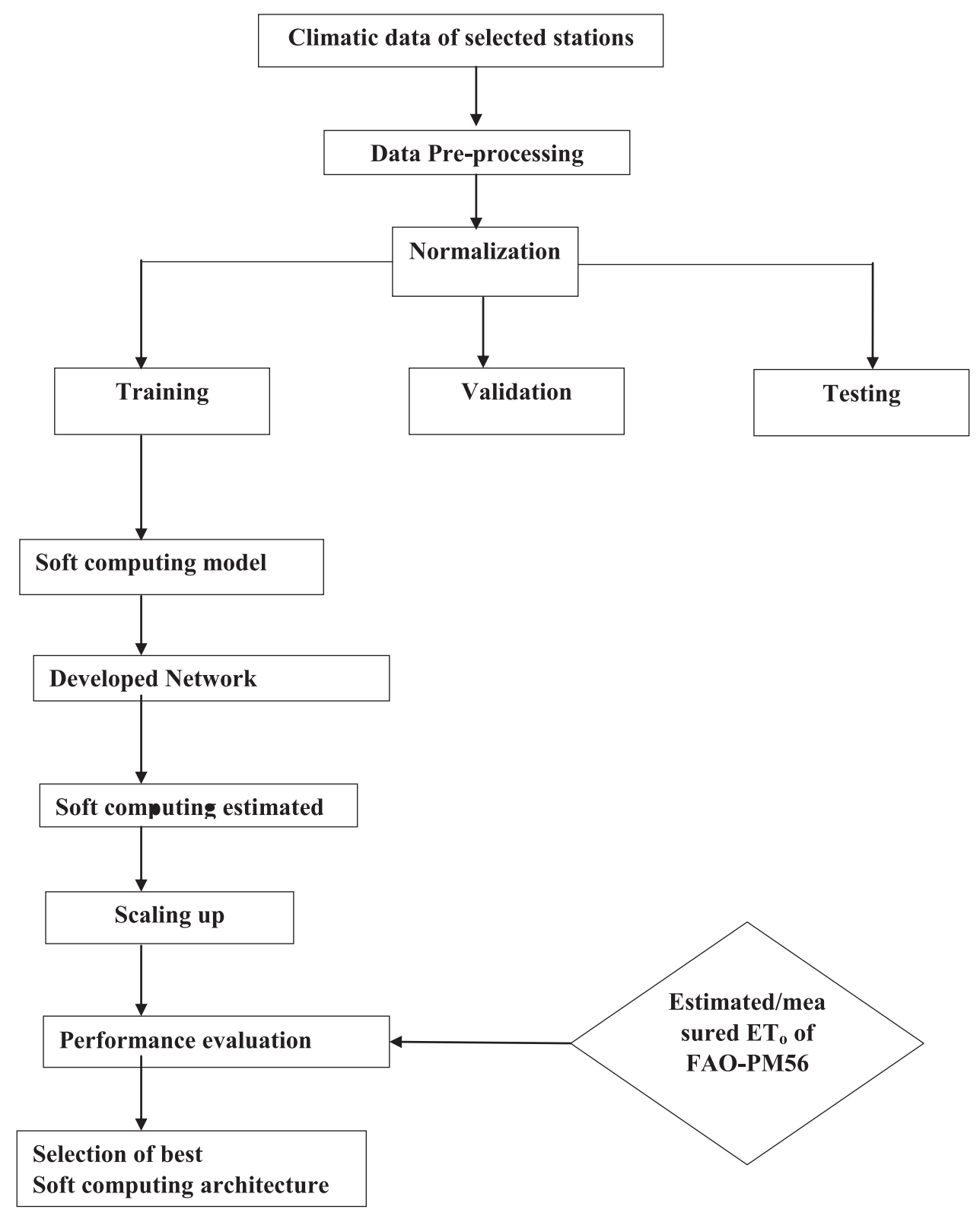

Fig. 1. Development of soft computing model.

only 29 full-text research articles were considered suitable and completely investigated in this study. The PRIZMA flow diagram as per instructions was made which is presented in Fig. 2. The research articles in accordance with inclusion criteria were downloaded. The adopted methodology and obtained results of these selected articles were evaluated and finally included in this review. The following attributes were noted from included articles: (i) input/target data, (ii) study duration, (iii) time step, (iv) study origin, (v) best soft computing model, (vi) model evaluation parameters, (vii) study used other countries climatic data.

\section{Data Type and Size}

Before the implementation of a soft computing model, it is necessary to check the type of selected data. Numerous researches indicate that different data division ratios were performed in training and testing phases when using soft computing models. There is no hard and fast rule to divide the data of training and testing phases in specific ratio but rarely $50 / 50$ or $60 / 40$ or $90 / 10$, while mostly $70 / 30$, have been applied in previous studies. A case study conducted on computation of daily solar radiation using wavelet and support vector machines divided available data set into 90/10 ratio for training and testing phases [20]. The reported articles [21-23] divided climatic dataset into $50 \%, 20 \%$ and $30 \%$ for training, validation and testing phases. With the recent development in soft computing models, the data points inside the training phase could be validated, therefore dataset could only be divided into training and testing phases [24-27]. 


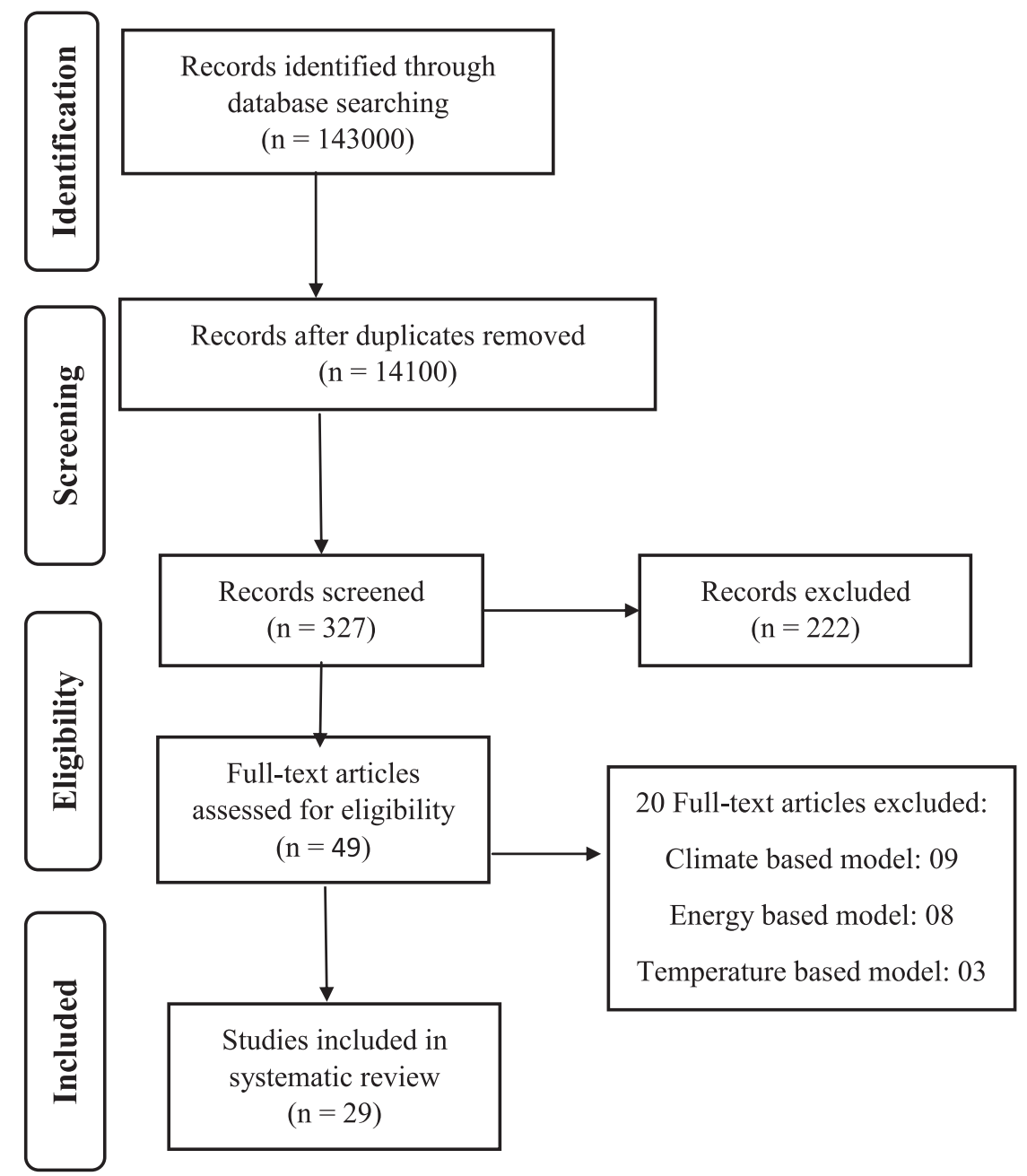

Fig. 2. PRISMA flow diagram.

\section{Selected Reviewed Articles}

The recently published studies on $\mathrm{ET}_{\mathrm{o}}$ estimation not later than 8 years ago (2012-2020) were included and evaluated which are in the English language and available in full text.

\section{Evaluation and Assessment}

In this study, reported articles (2012-2020) have been reviewed on basis of accuracy, structure and its usefulness.

\section{Accuracy}

The accuracy of soft computing models was investigated through a set of various indicators and/or indices. The commonly used performing indices are Pearson correlation coefficient (r2), Linear regression coefficient (R2), Nash-sutcliffe efficiency (NSE), Mean absolute error (MAE), Root mean square error (RMSE), Mean absolute percentage error (MAPE) and scatter index (SI) which can be determined as: $\mathrm{r}^{2}=\frac{\left[\mathrm{n} \times\left\{\sum_{\mathrm{i}=1}^{\mathrm{n}}\left\{\left(\mathrm{ET}_{\text {obs }} \times \overline{\mathrm{ET}}_{\mathrm{est}}\right)\right\}\right]-\left[\left\{\left(\sum_{\mathrm{i}=1}^{\mathrm{n}} \mathrm{ET}_{\text {obs }}\right) \times\left(\sum_{\mathrm{i}=1}^{\mathrm{n}} \mathrm{ET}_{\text {est }}\right)\right\}\right]\right.}{\sqrt{\left[\mathrm{n} \times\left\{\sum_{\mathrm{i}=1}^{\mathrm{n}}\left(\mathrm{ET}_{\mathrm{obs}}\right)^{2}\right]-\left[\left\{\left(\sum_{\mathrm{i}=1}^{\mathrm{n}} \mathrm{ET}_{\text {obs }}\right)\right\}^{2}\right] \times\left[\mathrm{n} \times\left\{\sum_{\mathrm{i}=1}^{\mathrm{n}}\left(\mathrm{ET}_{\mathrm{est}}\right)\right\}^{2}\right]-\left[\left\{\left(\sum_{\mathrm{i}=1}^{\mathrm{n}} \mathrm{ET}_{\mathrm{est}}\right)\right\}^{2}\right]\right.}}$

$$
\mathrm{R}^{2}=\frac{\left[\left(\sum_{\mathrm{i}=1}^{\mathrm{n}}\left(\mathrm{ET}_{\text {obs }}-\overline{\mathrm{ET}_{\text {obs }}}\right) \times\left(\mathrm{ET}_{\text {est }}-\overline{\overline{\mathrm{TT}_{\text {est }}}}\right)\right]^{2}\right.}{\left[\left(\sum_{\mathrm{i}=1}^{\mathrm{n}}\left(\mathrm{ET}_{\mathrm{obs}}-\overline{\mathrm{ET}_{\text {obs }}}\right) \times\left(\mathrm{ET}_{\text {est }}-\overline{\mathrm{ET}_{\text {est }}}\right)\right]\right.}
$$

$N S E=1-\frac{\sum_{i=1}^{N}\left(E T_{o b s}-E T_{\text {sim }}\right)}{\sum_{i=1}^{N}\left(E T_{o b s}-\overline{E T_{o b s}}\right)}$

$$
M A E=\sum_{i=1}^{N} \frac{\left|E T_{o b s}-E T_{\text {sim }}\right|}{N}
$$

$$
\text { MAPE }=\frac{100 \%}{\mathrm{~N}} \sum_{\mathrm{i}=1}^{\mathrm{N}}\left|\frac{\mathrm{ET}_{\text {obs }-\mathrm{ET}_{\text {est }}}}{\mathrm{ET}_{\text {obs }}}\right|
$$

$$
R M S E=\sqrt{\sum_{i=1}^{N} \frac{\left(E T_{o b s}-E T_{e s t}\right)^{2}}{N}}
$$

$$
S I=\frac{R M S E}{E T_{\text {mean }}}
$$

\section{Structure}

The structure of soft computing model depends upon its input/output dataset, neurons and activation 


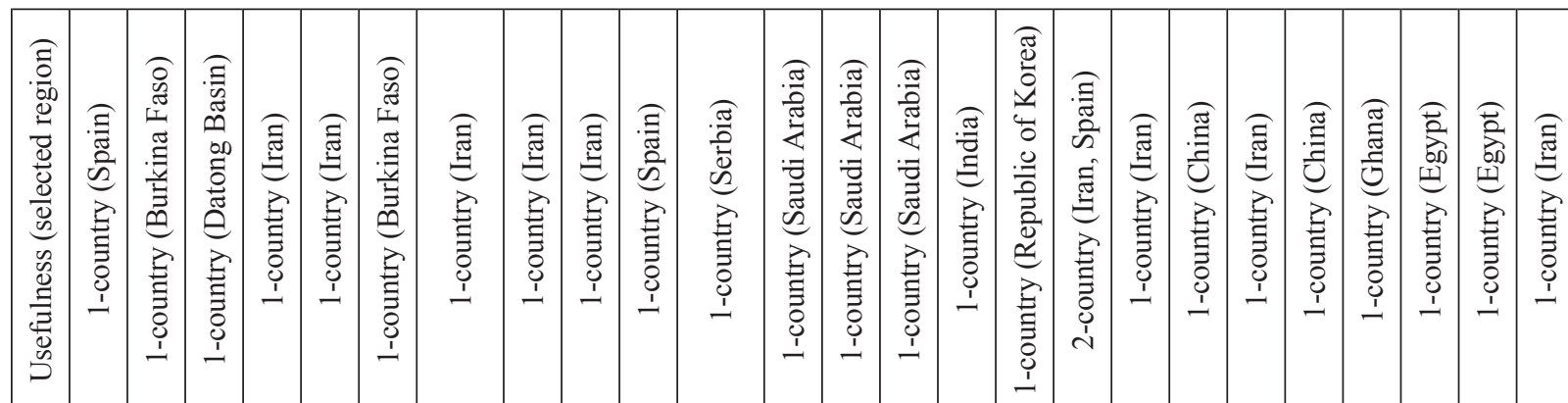

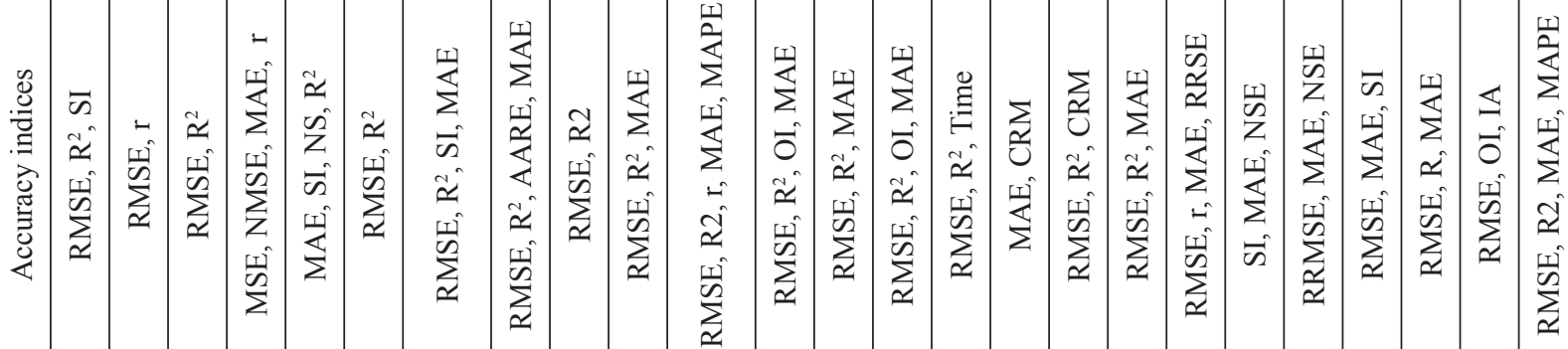

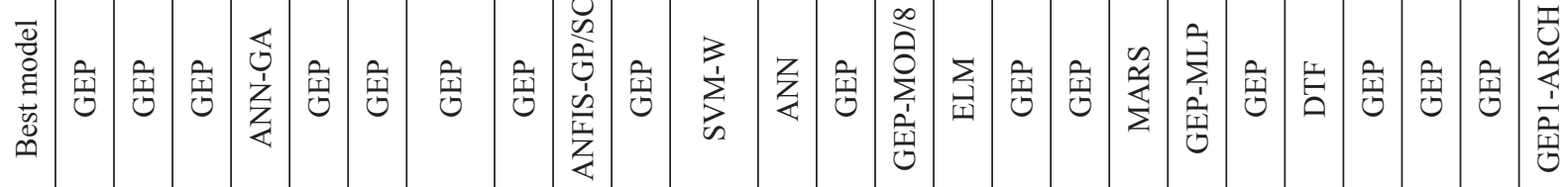

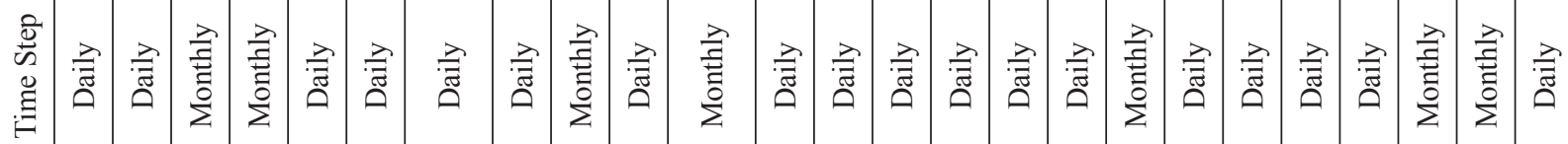

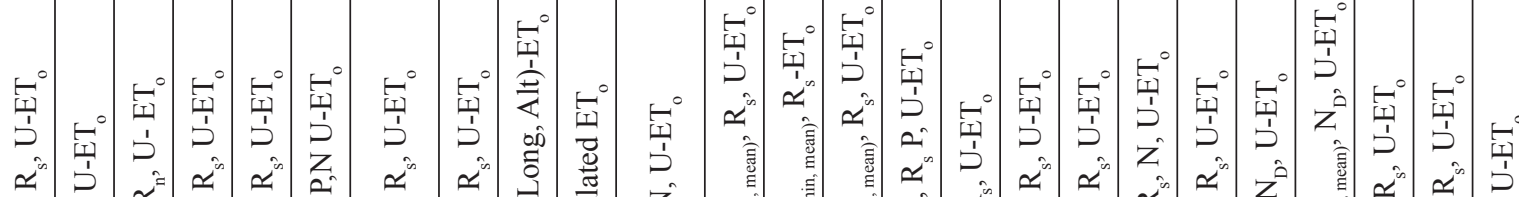

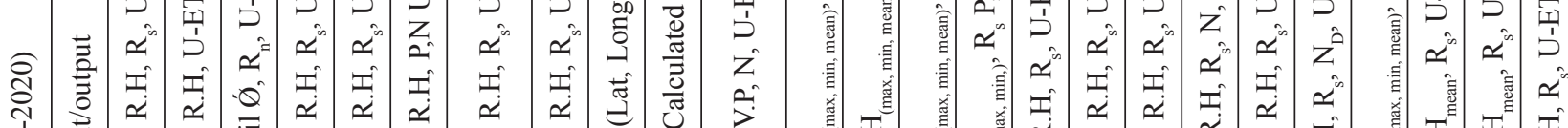

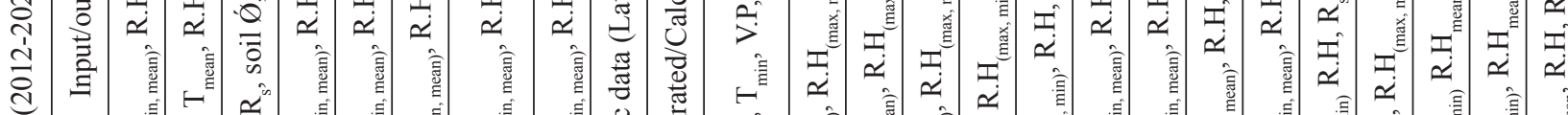

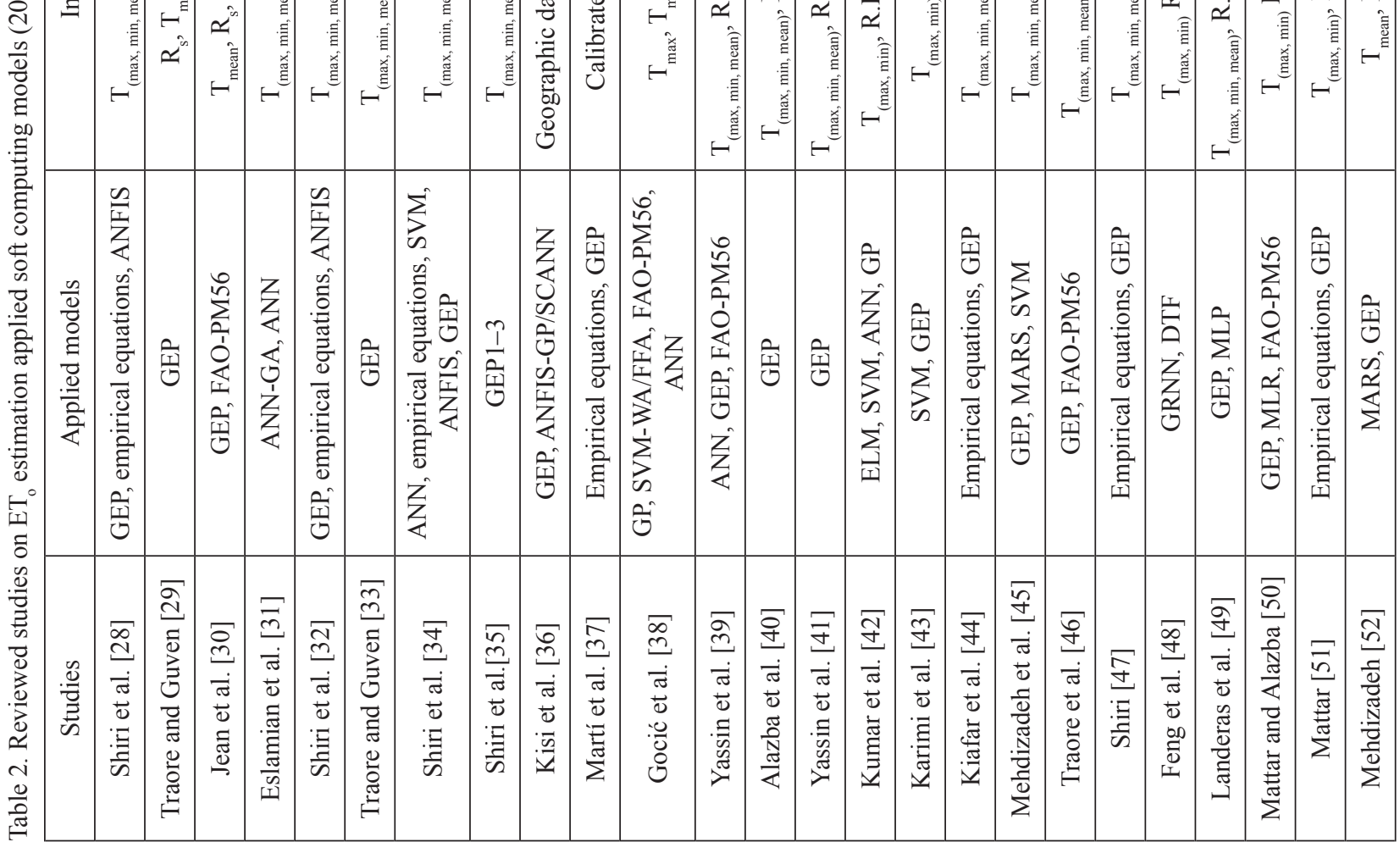




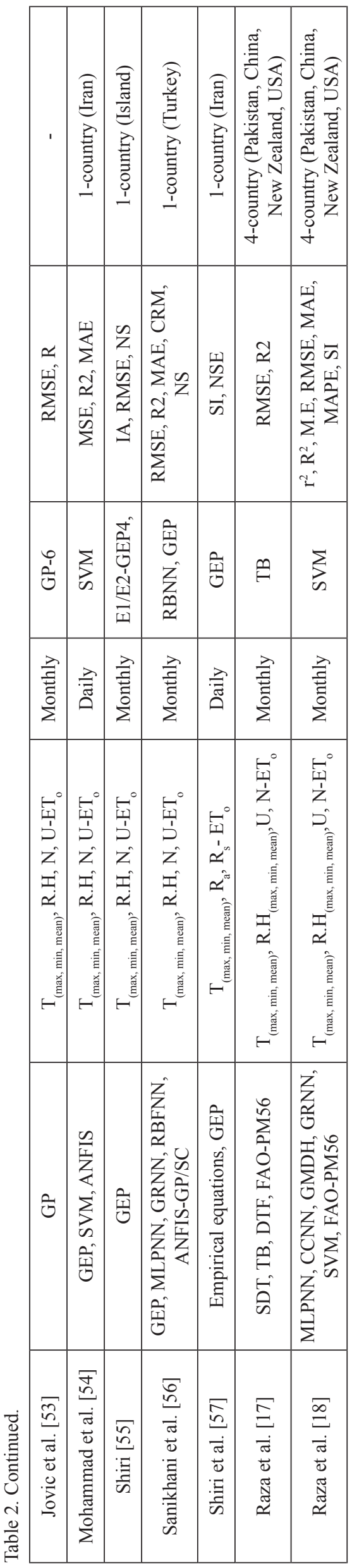

functions. In case of artificial intelligence (AI) based soft computing models [17], neurons in input/hidden/output layers accounted preeminent factor for determining structure of model. Alternatively, the structure in tree based soft computing models could be determined by considering its depth, size and level [18]. However, the models based on gene expression programming (GEP) formulated an equation for determining input-output relationship.

\section{Flexibility/Usefulness}

The empirical/semi empirical equations for estimation of ET developed in past studies are limited to site specific or particular climatic region (Table 1). When these equations applied in other climatic condition, the results found are not acceptable. Although, FAO-PM56 equation removed this barrier and applied worldwide for calculation of $\mathrm{ET}_{\mathrm{o}}$ but restricted its applicability in absences of climatic data. The information of maximum and minimum temperature only accessible in climatic stations of developing countries which restricted the use of FAO-PM56 equation in these locations. Therefore, development of alternative approaches/methods/models with less require climatic parameters is essential for $\mathrm{ET}_{\mathrm{o}}$ estimation. The flexibility/usefulness of $\mathrm{ET}_{\mathrm{o}}$ studies applied soft computing models were evaluated on basis of number of various climatic regions and fewer meteorological input.

The advantages of soft computing models are: (1) based on human reasoning which is inspired by the human brain in decision making, (2) ability to solve complex problems using multiplex algorithms, (3) ability to quickly learn from given dataset, (4) approximation, uncertainty and partial truth used as key elements to attain high level results, (5) unlike numerical modeling, develop approximation model using approximate reasoning and modeling, (6) provide solution with fast computing and zero cost. However, the main challenges and issues raised in various soft computing models are: (1) the evaluation of systematic and haphazard suspicions, (2) reduction in over fitting during training and testing process, (3) applicability of the model to provide efficient results for untrained data, (4) proper configuration of suitable tools for appropriate prediction, (5) the quality and quantity of available climatic data, (6) the availability of appropriate experimental observations.

\section{Reviewed Articles}

The summary of research articles reviewed in this study is presented in Table 2. It can be perceived that many studies have been conducted on $\mathrm{ET}_{\mathrm{o}}$ estimation using soft computing models. The main reason for preferring soft computing models in estimating $\mathrm{ET}_{\mathrm{o}}$ their capability to provide explicit formulation and ease of application. The formulation provided by GEP can 
be simply used in practical applications. Most studies have demonstrated a limitation in the predictability of soft computing models using fewer climatic parameters as input. This was observed more prominently in different climatic conditions such as arid, semi-arid and humid regions. This can best be explained by the $\mathrm{ET}_{0}$ processes being influenced by multiple climate variables and thus varying from one case to another. Based on the observations, soft computing models in such regions need several pieces of climate information for $\mathrm{ET}_{\mathrm{o}}$ estimation to attain reliable results. The recently reported research articles on ET $\mathrm{E}_{\mathrm{o}}$ estimation using soft computing models have been addressed below.

Table 2 revealed that mostly studies applied full climate data as inputs in the FAO-PM56 method for $\mathrm{ET}_{\mathrm{o}}$ estimation. The prime objective of the reported researches is to develop alternative soft computing model against FAO-PM56 because it requires large number of climate data as input and these data are not available at many stations, particularly in developing countries. So, it's not worth to design soft computing models using all the data that are usable, similar to FAO-PM56. Since, $\mathrm{ET}_{\mathrm{o}}$ can be determined with the FAO-PM56 if data are available for all meteorological variables, development of soft computing models with all input parameters is not advisable.

The creation of a separate $\mathrm{ET}_{\mathrm{o}}$ model with help of soft computing approaches for each station is another important matter. In addition, the development of a generalized $\mathrm{ET}_{0}$ model for the accurate $\mathrm{ET}_{0}$ estimation in all stations within an area has been considered by a small number of studies such as [17, 18, 44]. This becomes significant in case of developing countries where climatic data of mostly stations is missing or not available due to technical issues. Thus, the development of $\mathrm{ET}_{\mathrm{o}}$ model with fewer climatic inputs (e.g. temperature data) is mainly requisite. Also, it should be further inspected to determine $\mathrm{ET}_{\mathrm{o}}$ for those stations where nearby station or pooled data is considered.

\section{Conclusion}

In this review, the potential of soft computing models on $\mathrm{ET}_{0}$ estimation has assessed and evaluated in a detailed way. It was determined that soft computing models have been applied to develop $\mathrm{ET}_{0}$ models over the diverse climatic conditions. The results of accuracy indices indicated potential improvement in $\mathrm{ET}_{\mathrm{o}}$ estimation using soft computing models. However, structural and usefulness of soft computing models found limited and needs to be more clearly addressed. Based on review of research articles, the study has made some possible guidelines as future direction: (1) apply soft computing models with only maximum and minimum temperature data as easily accessible for each location, (2) The simply temperature-based $\mathrm{ET}_{\mathrm{o}}$ models should develop and use for the reliable projection of
$\mathrm{ET}_{\mathrm{o}}$ under climate change scenarios, (3) try to construct global soft computing model to estimate $\mathrm{ET}_{\mathrm{o}}$ at least in homogeneous climatic region, (4) use of novel soft computing models based on different algorithms, hybrid, wavelet, extreme learning approaches which has not yet applied on ET estimation, (5) deep learning models have applied and found outperformed in other fields but not yet explore in ET estimation, (6) Integration of geographical information system (GIS) and satellite data in water resources management and hydrological modeling issues. Climatic data retrieved form geographic information system (GIS) and satellite must try for spatial modeling of ET. For this purpose, high-resolution satellite climatic data as input can be used. This strategy will be helpful where weather stations are uncommon or climatic data is missing. In addition, the developed $\mathrm{ET}_{\mathrm{o}}$ models are station specific and even not work in station of same climatic region, therefore it is a dire need to include available data from all the stations and make a generalized model to estimate $\mathrm{ET}_{\mathrm{o}}$ for a whole country or at least homogenous climatic regions. The recently modified form of soft computing models based on deep learning techniques outperformed due to fastest learning process and handling of millions or even billions of neuronsweights but not yet explore in $\mathrm{ET}_{\mathrm{o}}$ estimation.

\section{Acknowledgements}

We are highly thankful to the Editor and anonymous Reviewers for their helpful comments. In addition, the co-authors equally contributed in preparation of this manuscript.

\section{Conflict of Interest}

The authors claimed no conflict of interest in this article.

\section{References}

1. AMARASINGHE U.A., SMAKHTIN V. Global water demand projections: past, present and future. International Water Management Institute (IWMI). 156, 32, 2014.

2. SUMMIT SHERMA R.D.G. Prediction of Evapotranspiration by Artificial Neural Network and Conventional Methods International Journal of Engineering Research. 5 (1), 184, 2016.

3. ŁABĘDZKI L., KANECKA-GESZKE E., BAK B., SLOWINSKA S. Estimation of reference evapotranspiration using the FAO Penman-Monteith method for climatic conditions of Poland. Evapotranspiration, InTech. Prof. Leszek Labedzki Ed.; Poland. 2011.

4. NOURI H., BEECHAM S., KAZEMI F., HASSANLI A., ANDERSON S. Remote sensing techniques for predicting evapotranspiration from mixed vegetated surfaces. 
Hydrology and Earth System Sciences Discussions. 10 (3), 3897, 2013.

5. LU G., WU Z., HE H. Hydrological Cycle and Quantity Forecast. Science Press: Beijing, 2010 [In Chinese].

6. ZHAO L., XIA J., XU C.-Y., WANG Z., SOBKOWIAK L., LONG C. Evapotranspiration estimation methods in hydrological models. J. Geogr. Sci, 23 (2), 359, 2013.

7. KARIMALDINI F., TEANG SHUI L., AHMED MOHAMED T., ABDOLLAHI M., KHALILI N. Daily evapotranspiration modeling from limited weather data by using neuro-fuzzy computing technique. Journal of Irrigation and Drainage Engineering, 138 (1), 21, 2011.

8. MCMAHON T., PEEL M., LOWE L., SRIKANTHAN R., MCVICAR T. Estimating actual, potential, reference crop and pan evaporation using standard meteorological data: a pragmatic synthesis. Hydrology and Earth System Sciences, 17 (4), 1331, 2013.

9. VINUKOLLU R.K., WOOD E.F., FERGUSON C.R., FISHER J.B. Global estimates of evapotranspiration for climate studies using multi-sensor remote sensing data: Evaluation of three process-based approaches. Remote Sensing of Environment, 115 (3), 801, 2011.

10. VALIANTZAS J.D. Simplified forms for the standardized FAO-56 Penman-Monteith reference evapotranspiration using limited weather data. Journal of Hydrology, 505, 13, 2013.

11. ALLEN R.G., PEREIRA L.S., RAES D., SMITH M. Crop evapotranspiration-Guidelines for computing crop water requirements-FAO Irrigation and drainage paper 56. Fao, Rome, 300 (9), 5109, 1998.

12. RAHIMIKHOOB A. Estimation of evapotranspiration based on only air temperature data using artificial neural networks for a subtropical climate in Iran. Theoretical and Applied Climatology, 101 (1), 83, 2010.

13. TRAJKOVIC S., KOLAKOVIC S. Estimating reference evapotranspiration using limited weather data. Journal of irrigation and drainage engineering, 135 (4), 443, 2009.

14. GAVILAN P., BERENGENA J., ALLEN R.G. Measuring versus estimating net radiation and soil heat flux: impact on Penman-Monteith reference ET estimates in semiarid regions. Agricultural Water Management, 89 (3), 275, 2007.

15. KUMAR R.,SHANKAR V., KUMAR M. Modelling of Crop Reference Evapotranspiration: A Review. Universal Journal of Environmental Research Technology, 1 (3). 239, 2011.

16. IBRAHIM D. An Overview of Soft Computing. Procedia Computer Science, 102, 34, 2016.

17. RAZA A., SHOAIB M., KHAN A., BAIG F., FAIZ M.A., KHAN M.M. Application of non-conventional soft computing approaches for estimation of reference evapotranspiration in various climatic regions. Theoretical and Applied Climatology. 139 (3), 1459, 2020.

18. RAZA A.S., SHOAIB M., FAIZ M.A., BAIG F., KHAN M.M., ULLAH M.K., ZUBAIR M. Comparative Assessment of Reference Evapotranspiration Estimation Using Conventional Method and Machine Learning Algorithms in Four Climatic Regions. Journal of Pure and applied geophysics. CF Alexander Rabinovich, Ed: 30, Switzerland, 2020.

19. HUANG Y., LAN Y., THOMSON S.J., FANG A., HOFFMANN W.C., LACEY R.E. Development of soft computing and applications in agricultural and biological engineering. Computers and Electronics in Agriculture, 71 (2), 107, 2010.
20. KIM J.H., CHOI Y.H., NGO T.T., CHOI J., LEE H.M., CHOO Y.M., LEE E.H., SADOLLAH A., JUNG D. KU battle of metaheuristic optimization algorithms 1: development of six new/improved algorithms. Harmony Search Algorithm. Kim J, Geem Z (eds); 197, Berlin, 2016.

21. TABARI H., KISI O., EZANI A., TALAEE P.H. SVM, ANFIS, regression and climate based models for reference evapotranspiration modeling using limited climatic data in a semi-arid highland environment. Journal of Hydrology. 444, 78, 2012.

22. KISI O., ZOUNEMAT-KERMANI M. Comparison of two different adaptive neuro-fuzzy inference systems in modelling daily reference evapotranspiration. Water resources management. 28 (9), 2655, 2014.

23. SHIRI J., SADRADDINI A.A., NAZEMI A.H., KISI O., LANDERAS G., FARD A.F., MARTI P. Generalizability of gene expression programming-based approaches for estimating daily reference evapotranspiration in coastal stations of Iran. Journal of hydrology. 508, 1, 2014.

24. SHOAIB M., SHAMSELDIN A.Y., MELVILLE B.W. Comparative study of different wavelet based neural network models for rainfall-runoff modeling. Journal of Hydrology. 515, 47, 2014.

25. SHOAIB M., SHAMSELDIN A.Y., MELVILLE B.W., KHAN M.M. Runoff forecasting using hybrid wavelet gene expression programming (WGEP) approach. Journal of Hydrology. 527, 326, 2015.

26. SHOAIB M., SHAMSELDIN A.Y., MELVILLE B.W., KHAN M.M. A comparison between wavelet based static and dynamic neural network approaches for runoff prediction. Journal of hydrology. 535, 211, 2016.

27. SANIKHANI H., KISI O., MAROUFPOOR E., YASEEN Z.M. Temperature-based modeling of reference evapotranspiration using several artificial intelligence models: application of different modeling scenarios. Theoretical and Applied Climatology. 135 (1), 449, 2019.

28. SHIRI J., KIȘI Ö., LANDERAS G., LÓPEZ J.J., NAZEMI A.H., STUYT L.C.P.M. Daily reference evapotranspiration modeling by using genetic programming approach in the Basque Country (Northern Spain). Journal of Hydrology, 414-415, 302, 2012.

29. TRAORE S., GUVEN A. Regional-specific numerical models of evapotranspiration using gene-expression programming interface in sahel. Water Resources Management, 26 (15), 4367, 2012.

30. JEAN M., PAIX D., LANHAI L.I., JIWEN G.E., JEAN N., VERENYAM A. Water losses in arid and semiarid zone: Evaporation, evapotranspiration and seepage. Journal of Mountain Science, 9, 256, 2012.

31. ESLAMIAN S.S., GOHARI S.A., ZAREIAN M.J., FIROOZFAR A. Estimating Penman-Monteith reference evapotranspiration using artificial neural networks and genetic algorithm: A case study. Arabian Journal for Science and Engineering, 37 (4), 935, 2012.

32. SHIRI J., MARTI P., KISI O., LANDERAS G., FARD A.F., NAZEMI A.H., SADRADDINI A.A. Evaluation of different data management scenarios for estimating daily reference evapotranspiration. Hydrology Research, 44 (6), 1058, 2013

33. TRAORE S., GUVEN A. New algebraic formulations of evapotranspiration extracted from gene-expression programming in the tropical seasonally dry regions of West Africa. Irrigation Science, 31 (1), 1, 2013.

34. SHIRI J., NAZEMI A.H., SADRADDINI A.A., LANDERAS G., KISI O., FAKHERI FARD A., MARTI P. 
Comparison of heuristic and empirical approaches for estimating reference evapotranspiration from limited inputs in Iran. Computers and Electronics in Agriculture, 108, 230, 2014

35. SHIRI J., SADRADDINI A.A., NAZEMI A.H., KISI O., LANDERAS G., FAKHERI FARD A., MARTI P. Generalizability of gene expression programmingbased approaches for estimating daily reference evapotranspiration in coastal stations of Iran. Journal of Hydrology, 508, 1, 2014.

36. KISI O., SANIKHANI H., ZOUNEMAT-KERMANI M., NIAZI F. Long-term monthly evapotranspiration modeling by several data-driven methods without climatic data. Computers and Electronics in Agriculture, 115, 66, 2015.

37. MARTÍ P., GONZÁLEZ-ALTOZANO P., LÓPEZURREA R., MANCHA L.A., SHIRI J. Modeling reference evapotranspiration with calculated targets. Assessment and implications. Agricultural Water Management, 149, 81, 2015.

38. GOCIĆ M., MOTAMEDI S., SHAMSHIRBAND S., PETKOVIĆ D., CH S., HASHIM R., ARIF M. Soft computing approaches for forecasting reference evapotranspiration. Computers and Electronics in Agriculture, 113, 164, 2015.

39. YASSIN M.A., ALAZBA A.A., MATTAR M.A. Artificial neural networks versus gene expression programming for estimating reference evapotranspiration in arid climate. Agricultural Water Management, 163, 110, 2016a.

40. ALAZBA A.A., YASSIN M.A., MATTAR M.A. Modeling daily evapotranspiration in hyper-arid environment using gene expression programming. Arabian Journal of Geosciences, 9 (3), 202, 2016.

41. YASSIN M.A., ALAZBA A.A., MATTAR M.A. Comparison between gene expression programming and traditional models for estimating evapotranspiration under hyper arid conditions. Water Resources, 43 (2), 412, 2016 b.

42. KUMAR D., ADAMOWSKI J., SURESH R., OZGAZIELINSKI B. Estimating evapotranspiration using an extreme learning machine model: Case study in North Bihar, India. Journal of Irrigation and Drainage Engineering, 142 (9), 1, 2016.

43. KARIMI S., KISI O., KIM S. Modelling daily reference evapotranspiration in humid locations of South Korea using local and cross-station data management scenarios. International Journal of Climatology, 37, 3238, 2017.

44. KIAFAR H., BABAZADEH H., MARTI P., KISI O., LANDERAS G., KARIMI S., SHIRI J. Evaluating the generalizability of GEP models for estimating reference evapotranspiration in distant humid and arid locations. Theoretical and Applied Climatology, 130 (1-2), 377, 2017.

45. MEHDIZADEH S., BEHMANESH J., KHALILI K. Using MARS, SVM, GEP and empirical equations for estimation of monthly mean reference evapotranspiration. Computers and Electronics in Agriculture, 139, 103, 2017.
46. TRAORE S., LUO Y., FIPPS G. Gene-expression programming for short-term forecasting of daily reference evapotranspiration using public weather forecast information. Water Resources Management, 31 (15), 4891, 2017.

47. SHIRI J. Evaluation of FAO56-PM, empirical, semiempirical and gene expression programming approaches for estimating daily reference evapotranspiration in hyperarid regions of Iran. Agricultural Water Management, 188, 101, 2017.

48. FENG Y., CUI N., GONG D., ZHANG Q., ZHAO L. Evaluation of random forests and generalized regression neural networks for daily reference evapotranspiration modelling. Agricultural Water Management, 193, 163, 2017.

49. LANDERAS G., BEKOE E., AMPOFO J., LOGAH F., DIOP M., CISSE M., SHIRI J. New alternatives for reference evapotranspiration estimation in West Africa using limited weather data and ancillary data supply strategies. Theoretical and Applied Climatology, 132, 701, 2018.

50. MATTAR M.A., ALAZBA A.A. GEP and MLR approaches for the prediction of reference evapotranspiration. Neural Computing and Applications, 1, 2018.

51. MATTAR M.A. Using gene expression programming in monthly reference evapotranspiration modeling: A case study in Egypt. Agricultural Water Management, 198, 28, 2018.

52. MEHDIZADEH S. Estimation of daily reference evapotranspiration (ETo) using artificial intelligence methods: Offering a new approach for lagged ETo databased modeling. Journal of Hydrology, 559, 794, 2018.

53. JOVIC S., NEDELJKOVIC B., GOLUBOVIC Z., KOSTIC N. Evolutionary algorithm for reference evapotranspiration analysis.Computers and Electronics in Agriculture, 150 (4), 1, 2018.

54. MOHAMMAD O., POUR R., PIRI J., KISI O. Comparison of SVM, ANFIS and GEP in modeling monthly potential evapotranspiration in arid region (case study: Sistan and baluchestan province -Iran). Water Science Technology, 19 (2), 392, 2018.

55. SHIRI J. Modeling reference evapotranspiration in island environments: Assessing the practical implications. Journal of Hydrology, 570 (1), 265, 2019.

56. SANIKHANI H., KISI O., MAROUFPOOR E., YASEEN Z.M. Temperature-based modeling of reference evapotranspiration using several artificial intelligence models: Application of different modeling scenarios. Theoretical and Applied Climatology, 135 (1-2), 449, 2019.

57. SHIRI J., MARTI P., KARIMI S., LANDERAS G. Data splitting strategies for improving data driven models for reference evapotranspiration estimation among similar stations. Computers and Electronics in Agriculture, 162 (3), 70, 2019. 